\title{
POSTGRADUATE EDUCATION OF DOCTORS: CURRENT STATE AND PERSPECTIVES
}

\author{
Yaroslav Tsekhmister \\ Doctor of Sciences in Pedagogy, Professor \\ Corresponding member of the National Academy of Educational Sciences of Ukraine \\ First pro-rector on scientific pedagogical activity \\ Bogomolets National Medical University, Ukraine \\ Ya.Tsekhmister@gmail.com \\ $+380442344062$ \\ ORCID ID 0000-0002-7959-3691
}

\author{
Oleksandra Lysenko \\ $\mathrm{PhD}$ \\ Deputy director in Institute of postgraduate education \\ Bogomolets National Medical University, Ukraine \\ A.Yu.Lysenko@gmail.com \\ $+380442344062$ \\ ORCID ID 0000-0001-9356-1306
}

\section{ABSTRACT}

The article characterizes the system of postgraduate training of doctors in Ukraine, in particular it describes its organizational structure that is implemented through compulsory (internship and improvement) and variable (clinical residency, re-training, advanced training) components; defines the perspective for implementation of doctors' residency in our state; determines the expediency in implementation of centralized life-long education provision system through establishment of self-governing organization, which activity will be directed to provide with efficient informal function of system of continuous professional education for doctors.

Keywords: continuous professional education; education of doctors; life-long education; postgraduate.

\section{INTRODUCTION}

The current state of social and economic transformations that take place in Ukraine stipulates the necessity in updating and improving the existing system for training of specialists taking into consideration the processes, inherent to cultural globalization. Thereon, the issue on training of competitive human capital, being capable of the country's innovative development, personal self-fulfillment and satisfaction of public needs, becomes more and more urgent.

Health care system as the indicator for civil development of population is one of the top-priority directions in national policy. In this context, more and more attention should be paid to the task on improvement of staffing in medical sphere taking into consideration the international quality standards. Thus, the issue on formation of efficient system of life-long education that will provide possibilities for continuous professional development and improvement of doctors becomes important.

The objective of the article is to analyze the current state in postgraduate education of doctors in Ukraine, to define the perspectives for its improvement. 


\section{RESULTS AND THEIR DISCUSSION}

According to the Law on Higher Education of Ukraine, dd. July 01, 2014 No 1556-VII, postgraduate education is considered as "the specialized improvement of education and professional training of a person through deepening, enlarging and updating his or her knowledge, abilities and skills pursuant to higher education (specialty) or occupational technical education (occupation) and practical experience, having been acquired before" (Law on Higher Education, 2014).

As it concerns the system of doctors' training, the postgraduate stage in professional establishment is compulsory all over the world and aims to acquire the independent practical experience pursuant to the qualification, having been acquired before, according to International standards in medical education, which are presented by World Medical Education Federation (Copenhagen, 2013), in order to improve the quality of health care (Chen C., Kotliar D., Drolet B. C., 2015: p. 181).

Considering the structure for postgraduate training of doctors in Ukraine, it may conditionally be divided into compulsory and variable components (Figure 1). Thus, the compulsory forms of postgraduate training include: specialization (internship), which tasks are to improve the level of practical training at graduates from higher medical schools, to form their self-readiness for medical activity.

Today in Ukraine the study at internship is carried out due to 31 medical specialties (order from MHC of Ukraine, dd. 23. 02. 2005 No 81), and it results in awarding the qualification of doctor-specialist in case of successful fulfillment of requirements in curriculum and training program that is implemented during 1-3 years depending on specialty (order from MHC of Ukraine, dd. 19. 09. 1996 No 291).

However, it should be mentioned that according to the provision in Law of Ukraine "About higher education" in the nearest future it is planned to narrow the list of specialties, which mastery will be possible immediately after successful completion of pre-graduate stage in study. Further specialization with the purpose for mastery of particular specialty during two years of doctoral residency will become possible for persons, who have acquired the qualification of doctorspecialist before.

The next form of postgraduate education that is compulsory for all doctors is the improvement that anticipates further improvement of professional knowledge and skills in order to maintain the modern level of training and shall be carried out not less than once per five years (order from MHC of Ukraine, dd. 22. 07. 1993, No 166).

After passing through improvement the doctors are subject to attestations, which tasks are to confirm the title of doctor-specialist for next five years or to award the next doctoral category (second, first, highest). It is necessary to mention that awarding and further confirming of the doctoral category may be carried out provided that a specialist fulfills the requirements for available practical working experience, anticipated by regulatory legal base, as well as takes part in scientific educational events.

As it concerns the variable component of postgraduate education, it should include clinical residency, specialization (re-training), advanced training (over improvement, defined by legislation). 
Clinical residency is the form for training of doctor-specialist in order to acquire the highest qualification pursuant to education, having been obtained before, and acquired experience of practical work in a certain occupation.

Specialization (re-training) is carried out due to specialties that are not anticipated while learning the primary specialization at internship. So, for comparison, it is necessary to mention that the Guide of qualifications characteristics for occupations of workers in health care system, approved by the order from Ministry of Health Care of Ukraine on March 29, 2002 No 117, defines over 130 doctoral occupations, while as it has already been mentioned above, the training at internship is carried out only due to 31 of them. For example, a person, who wishes to work as a doctor-cardiologist has firstly to receive the title of doctor-specialist due to specialty "internal diseases" after completion of a two-year study at internship and only after that to pass through specialization in cardiology that lasts three months.

As it concerns the advanced training over improvement, defined by legislation, it should include probation, participation in scientific practical conferences, seminars, trainings, etc.

In our opinion, namely this stage in postgraduate education is the most significant one within the context of continuous professional development at doctors, being capable of constant self-improvement all lifelong in order to solve a totality of problems that now arise to health care system in the whole world civilization (Tsekhmister, 2002: p. 39). However it should be mentioned that the mechanism for implementation of idea about continuous professional education is insufficiently arranged in the territory of our country.

While discussing this problem it is necessary to take into consideration that self-education at the current stage in economic development of the country is often lost by practical doctors and acquires only the formal significance in order to confirm the specialty/qualification category acquired before. Rather often educational and scientific innovations are available only for scientific, scientific pedagogical workers, as well as for persons, who work at powerful specialized dedicated regional centers.

Taking into consideration the current state of affairs, it becomes urgent to improve the role of public organizations in system of postgraduate education for doctors. Thus, in terms of international experience in doctoral self-government, in particular, practice on existence of medical education associations, as well as peculiarities for national system of doctors' training, it is reasonable to establish the specialized all-Ukrainian public organization, which activity will be directed to provide with efficient informal function of system for continuous professional education of doctors. In our opinion, the abovementioned structure will assist to implementation of the following strategic tasks that are set to current Ukrainian society:

- $\quad$ development of health care system in Ukraine;

- $\quad$ integration into European educational space;

- professional development of health care specialists;

- $\quad$ spread of ethical and deontological standards among doctors;

- improvement of training system and advanced training of health care specialists;

- $\quad$ provision with favorable conditions for continuous professional, cultural and creative development; 

in society;

improvement of positive image for medical and pharmaceutical occupation

- $\quad$ improvement of quality in training of medical and pharmaceutical staff.

The establishment of self-governing organization, suggested by us, acquires the special importance at consideration through the prism of andragogical learning principles, in particular, taking into consideration the requirements to the technology of creative educational activity that are especially urgent at work with adult pupils, who are doctors at the stage of postgraduate training, in particular: efficient use of academic time to improve the level of knowledge, abilities and skills; development of thinking and mastery of skills for research activity; receipt of new ideas and results, generalizations (both objectively and subjectively new); manifestation of individual achievements in cognitive sphere; establishment of own experience in activity and its approbation in practice (Sysoieva S. O., 2011: p. 90).

\section{CONCLUSIONS}

The existing system for postgraduate training of doctors in Ukraine is complex, graded and hierarchically successive with a wide range of means for implementation of programs for educational training. However, the issues on centralized organization of life-long learning process, provision with possibilities for equal access of doctors to programs of continuous professional education remain unsolved. Self-education at the current stage in economic development of the country is often lost by practical doctors and acquires only formal significance in order to confirm the specialty/qualification category, having been acquired before. Rather often educational and scientific innovations are available only for scientific, scientific pedagogical workers, as well as for persons, who work at powerful specialized dedicated regional centers. Thus, in terms of international experience in doctoral self-government, in particular, practice on existence of medical education associations, as well as peculiarities for national system of doctors' training, it is reasonable to establish the specialized all-Ukrainian public organization, which activity will be directed at provision of efficient informal function of system for continuous professional education of doctors.

\section{REFERENCES}

1. Guide of qualifications characteristics for occupations of workers in health care system. Retrieved from http://mozdocs.kiev.ua/view.php?id=4233

2. Sysoieva, S. (2011). Interactive learning technologies for adults: study guide. Kyiv: PH "Ecmo".

3. Tsekhmister, Y. (2002). Pre-professional training of pupils in lyceum of medical profile: theory and practice: monograph. Kyiv: Scientific thought.

4. Chen (Amy), C., Kotliar, D., Drolet, B. (2015). Medical education in the United States: do residents feel prepared? Perspect Med Educ., 4, 181-185.

5. Order from Ministry of health care of Ukraine, dd. 22.07.1993 No 166 "About further improvement of system for postgraduate training of doctors (pharmacists)”. Retrieved from http://zakon5.rada.gov.ua/laws/show/z0113-93

6. Order from Ministry of health care of Ukraine, dd. 19.09.1996 No 291 "About approval of Provisions about specialization (internship) at graduates from 
higher medical and pharmaceutical schools of III-IV accreditation levels, medical faculties of universities”. Retrieved from http://zakon0.rada.gov.ua/laws/show/ z0696-96.

7. Order from Ministry of health care of Ukraine, dd. 23.02.2005 No 81 "About approval of List of specialties and periods of study at internship for graduates from higher medical and pharmaceutical schools, medical faculties of universities". Retrieved from http://zakon3.rada.gov.ua/laws/show/z0291-05

8. Law of Ukraine "About higher education", dd. 01.07.2014 No 1556-VII. Retrieved from http://zakon3.rada.gov.ua/laws/show/1556-18 